\title{
The University of Florence and Pisa in the High Renaissance
}

\author{
PAUL F. GRENDLER
}

Scholars do not immediately think of its university when praising the contribution of Florence to the Renaissance. After a shaky start in 1321, the Republic reorganized the university in 1348, hoping that it would become both distinguished and profitable. Neither hope was realized in the fourteenth and first half of the fifteenth centuries, so the government gave it less and less support. ${ }^{1}$ The University of Pisa was founded in 1343, and, although it enjoyed greater fortune than the Studio of Florence, it, too, failed to achieve the eminence of such north Italian universities as Bologna and Padua. A new era for the University of Florence and Pisa began in December 1472 when Lorenzo de' Medici reorganized and combined the two. The university reopened in 1473 in two parts in two locations: the older Studio repubblicano remained in Florence as a faculty of rhetoric and poetry, while a Studio generale was founded in Pisa. Young Florentines usually pursued humanistic studies in Florence, and then went to Pisa to obtain degrees in law (the most populous faculty), medicine, natural philosophy, metaphysics, logic, and occasionally in rhetoric. The young Galileo Galilei joined Pisa as professor of mathematics in 1589. The Florentine section of the university lacked the corporate organization of its Pisan sibling and has attracted less notice, but was an important part of the intellectual life of the city.

Armando Verde's massive collection of documents and summaries of documents deals with the University of Florence and Pisa from 1473 until its temporary closure in 1503 . Verde has explored a host of archival sources, including the surviving university records in the state archives of Florence and Pisa, and many other civil and ecclesiastical repositories. In his search for social and economic data on the professors and students, he has traversed the uncharted sea of notarial records in the two cities. Anyone who has done this kind of "haystacking," i.e., looking through mounds of business and tax documents for information on individuals or members of a profession, can appreciate the effort involved. The first volume appeared in 1973: Armando F. Verde, Lo Studio Fiorentino 1473-1503: Ricerche e Documenti. 
Vol. I: Introduzione - Bibliografia - Ufficiali dello Studio - Rettori-Rotoli (Florence: Istituto Nazionale di Studi sul Rinascimento, 1973. Pp. xii + 394). It begins with a massive bibliography of printed works with the author's summaries and comments, and concludes with publication of documents from the Ufficiali dello Studio. This includes lists of the rectors, vice-rectors, and professors, 1473 through 1503 . It tells us when various professors taught and what they were paid. Generally speaking, the legists were best paid, followed by the professors of medicine, and finally those in the humanities and philosophy - but with substantial variation within each discipline. Both the general pattern and the inconsistencies are typical of an Italian Renaissance university. Some of the highly-paid professors were major intellectual figures; others accomplished little.

Volume Two also appeared in 1973: Vol. II: Docenti - Dottorati (Florence: Istituto Nazionale di Studi sul Rinascimento, 1973. Pp. 783). This volume presents information about the professors and known graduates, the majority in law and medicine. Verde offers in summary form both intellectual and social data that he has unearthed from notarial records, university documents, and other sources. Particularly interesting are several contemporary lists of books belonging to booksellers and individuals.

This brings us to the most recent volume to appear, Volume Three in two parts: Studenti - "Fanciulli a scuola" nel 1480 (Pistoia: Presso “"Memorie Domenicane”, 1977. Pp. lii + 1207 [paged continuously]). Perhaps these volumes focussing on the students provide the freshest and most interesting material that Verde has yet uncovered. Since the Libro delle matricole (matriculation lists) have not survived, Verde has had to reconstruct them from other sources. About 300 students annually attended the Pisan branch of the university in the years 1473 through 1503; Verde has discovered 150 to 160 names annually, and in a few years over 200 names. He has reconstructed one-half to two-thirds of the Pisan student body. Moreover, he has illuminated many aspects of their lives, including their living arrangements, quarrels, and marriages.

Verde has identified 1,296 students in the faculties of law, medicine, arts, and theology at Pisa. Two hundred eleven of these were clergymen. About half of the students came from Florence and the Florentine state. Another 400 came from other parts of Italy (110 from Sicily alone), and about 250 from non-Italian lands, including 88 Spanish, 54 Portuguese, and 42 French students. Verde does not compare the composition of the Pisan student body with other Italian universities; nevertheless, a few points can be made. The Studio at Pisa probably had fewer non-Italian students than did the more famous universities of Bologna and Padua. In particular, Pisa had relatively few German students, usually the largest contingent of foreigners at north Italian universities. The 
Germans - and the English, a much smaller group - were more likely to attend Padua than any other Italian university. The prestige of Padua and tradition led them south: German fathers, sons, and grandsons journeyed to Padu to obtain law degrees. Protestants from Germany and England continued to study at Padua after 1550, when the Counter Reformation was ascendant. Germans attending Tuscan universities were more likely to go to Siena, which in the fifteenth century was not yet subject to Florentine rule.

Proximity and the insistence of government that subjects study at the local university more than likely explain the large number of Florentines at Pisa. The large number of Sicilians possibly results from their being no university of stature in Sicily. Students from north and central Italy had the alternatives of Padua and Pavia; those in central Italy might attend the Roman Sapienza or Bologna. Indeed, Bologna's law school graduated many ambitious clergymen eager to serve in the papal court or diplomatic corps.

The famous and the not so famous studied at Pisa. Cesare Borgia studied there from 1491 through 1493, renting a house for the fairly high sum of twenty-five ducats (p. 219). So did Alessandro Farnese, the future Pope Paul III, and a host of Florentines, including Francesco Guicciardini and two future Medici popes.

Verde also searched for the young Florentines who studied at the faculty of rhetoric and poetry in Florence. To do this, he extended his investigation to include all Florentine scholars from the age of five or six upward, using the Florentine Catasto of 1480. Every few years the government levied a tax on the wealth of its subjects; all heads of households were obliged to declare their worth, but they might deduct living expenses for themselves and others residing at home. To claim these deductions, the head of the household was obliged to list the name, age, sex, and occupation, if any, of each member of the household. Since those attending school did not work at remunerative labor, they counted as expenses to the householder. Hence, a declaration lists a boy who "va ala scuola," (goes to school) or "stà a. lleggiere" (is learning to read, i.e., the lowest level of elementary school) or "istà al'abacho" (is studying commercial arithmetic).

Verde's documents show education through a broad spectrum of the Florentine population in 1480. Boys began their schooling at the age of five, and more often at six or seven. The children of the wealthy frequently received private tutoring at home, either from a teacher who lived with the family or one who came to the house daily. Sons of the fairly large middle class of merchants and professionals went to neighborhood private schools, i.e., schools set up by a local schoolmaster who received small fees from the parents of the pupils. Niccolo Machiavelli, who was eleven in 1480, and his 
younger brother Totto, aged five, studied in such a school. Their father Bernardo, not poor but far from wealthy, paid the fees (pp. 733, 923, 1028; also see vol. II, pp. 535-537). Not all the students came from the upper and middle classes. A boy aged twelve and a half attended school; his father worked as a "wool cleaner," and his two older brothers, aged twenty-two and twenty, were silk winders "when they can find work." The family's net worth was nothing (p. 1018). The brother of a cabinet-maker attended school, even though the head of the family had no wealth and the daughters no dowries (p. 1029). The Castasto records suggest that school attendance was practically universal for the sons of the upper and middle classes, and still widespread among humbler folk.

Children began by learning to read and write, and then passed quickly to the elements of Latin grammar and to the reading and memorization of Latin couplets. When the Florentine boy reached the age of eleven or twelve, he frequently spent about two years with a maestro d'abaco, a teacher who taught commercial arithmetic and the principles of accounting. Upon completing his course in commercial arithmetic, the boy might begin an apprenticeship with a merchant. Those who wished to attend university could bypass the commercial arithmetic school in favor of additional years mastering Latin, or could proceed from the commercial arithmetic school to a grammar school. Grammar school pupils, probably aged c. twelve to the middle or higher teens, studied Latin classics. It would be interesting to know how many Florentine boys in 1480 received what was probably university preparatory training in grammar schools, but there are insufficient references in Verde's documents to hazard a guess.

The teenage Florentine could attend the faculty of rhetoric and poetry in Florence in order to study under the famous humanists Cristoforo Landino (who taught there from 1473 through 1497) and Angelo Poliziano (1480 through 1494). But, because of the lack of a corporate structure and documents, it is impossible to determine how many did so and for how long. It is likely that both formal and informal study, i.e., auditing lectures without enrolling, were common. For example, no evidence shows that Niccolò Machiavelli attended the faculty of rhetoric and poetry, but it is hard to imagine him ignoring the opportunity to hear famous humanists lecturing on the classical historians. The students of the Florentine Studio in turn taught younger students. Niccolò di Michele Zeffi, age twenty, from a quite modest family, studied letters and also served as a ripetitore (literally "repeater," an assistant teacher or coach who drilled children in their lessons, such as the elements of Latin grammar) for four boys, aged nine, ten, twelve, and thirteen, in a wealthier household (pp. 743, 1015).

Boys studying for the priesthood were a small part of the student body. At times they studied in special schools, other times they lived at home and studied with a local priest. It is quite likely that aspiring clergymen often 
attended the humanistic faculty in Florence. As adults, many humanisticallytrained clergymen entered the teaching profession. In sixteenth-century Venice they comprised about $60 \%$ of the schoolmasters, both as private tutors and as the masters of neighborhood schools. ${ }^{2}$

The most difficult question is: how many girls attended school? The Catasto records are of little help, because the tax officials wanted to know the value of the girls' dowries, not the contents of their minds. Nevertheless, fragmentary evidence shows that some girls did obtain an education, sometimes a very good one in the studia humanitatis. Alessandra, daughter of the Florentine chancellor Bartolomeo Scala, and her three sisters studied with a private teacher, beginning at the age of five. At the age of eighteen, Alessandra was known for her proficiency in Greek (pp. 36-37). Verde has even come across a female teacher. He notes that a five-year-old boy "va a leggere cho' mona Chosa" (p. 1027); that is, the boy went outside the home to learn to read from "mona Chosa." It appears that the lady ran a primary school.

Verde opines that if the family had enough money to hire a tutor, girls as well as boys profited from the instruction. Girls in more modest circumstances possibly received whatever education other members of a household - parents, relatives, or brothers studying outside the home imparted. Probably the major reason why relatively few girls were formally educated is that they did not go outside the home. Nor did they attend university. The first known female university graduate was Elena Lucrezia Cornaro Piscopia (1646-84), daughter of a Venetian noble, who received a doctorate in philosophy from the University of Padua on June 23, 1678. (She wanted a theology degree, but ecclesiastical authorities objected.) The tercentary of her convocation was observed at some universities in Italy and the United States, as well as by several scholarly studies. $^{3}$

Verde provides the names of 1,035 children and young people, aged five through eighteen or nineteen, who attended school in Florence in 1480. One would like to know what percentage of schoolage children attended school, but not enough data is available to make an estimate. Moreover, Verde warns that the Catasto records do not provide a complete picture because some declarations are not extant and others fail to include all the children in school. If the family did not send them out of the home to study, no tax advantage could be gained by reporting them. Moreover, it is not known how many children studied in convents and monasteries as boarding students.

Still, it is tempting to compare Verde's figures with Giovanni Villani's famous comments on the number of children in school in Florence in the 1340s. Villani (d. 1348) stated in his Cronica that there were 8,000 to 10,000 boys and girls ("fanciulli e fanciulle") learning to read, another 
1,000 to 1,200 studying “abacus and algorism"' (arithmetic using arabic numbers), and about 550 to 600 studying grammar and logic in the grammar schools. ${ }^{4}$ The city had about 100,000 people just before the plague of 1348 ; in 1480 the figure was about $55,000 .{ }^{5}$ Since one doubts that a lesser percentage of schoolage children attended school in 1480 than a century earlier, it appears that Verde's 1,035 young scholars are a very useful sample but not the whole picture. Nevertheless, his invaluable information demonstrates that the number in school was large.

If a reviewer may speculate where the researcher is cautious, it looks as if Florentine education was similar to that in other Italian cities. Sixteenth-century Venice, for example, had a similar education system if such an uncoordinated mix of schools can be called a system. ${ }^{6}$ The children of the wealthy studied at home under private tutors. Other children were taught by independent schoolmasters in neighborhood schools. The government provided limited secondary education by paying the salaries of a handful of grammar masters. For higher education in humanistic studies and philosophy, boys might attend the Scuola di San Marco, a publicly-funded institution established in the fifteenth century to train future ducal secretaries. As in Florence, eminent humanists whose influence extended beyond the classroom sometimes taught in these schools. Finally, young Venetians might obtain law degrees at the nearby University of Padua.

Verde's rich collection of documents and summaries of documents is of great use to the historian of Renaissance universities and education. The work is not an historical synthesis, but a mass of sifted material for such a synthesis. At times one wishes that Verde would permit himself some generalizations, but he argues that history should not be "interpretation or philosophy," but "pure and simple knowledge of a process of life"' (p. xx). Scholars are deeply in Verde's debt for the information that he provides and his meticulous care and honesty in presenting it. Moreover, he promises future volumes on the "Vita Universitaria" and the "Stanziamenti per lo Studio," and a volume of indices. Readers are also grateful to the publishers and friends who funded this enterprise. The Istituto Nazionale di Studi sul Rinascimento published the first two volumes but could not continue. Individuals and organizations stepped in to support Volume Three, parts one and two, published by the Dominican house of studies in Pistoia. STudents of the period will recognize it as the publisher of Memorie Domenicane, an excellent annual volume of studies on humanism and the Renaissance.

Verde's fine study is the clearest, but not the only, sign of a revival of interest in the history of Renaissance education generally and of Renaissance universities in particular. Italian scholars, stimulated by national unification and the accompanying liberal ideology, intensely cultivated the field in the last twenty years of the nineteenth and the first two 
decades of the twentieth century. They produced a wealth of local studies, including editions of university statutes and biographies of individual teachers. However, only Giuseppe Manacorda, Storia della scuola in Italia. Il medio evo. (2 vols. Milan, Palermo, and Naples, 1913) offered a picture of education in the peninsula as a whole. Manacorda's study encompassed the fifteenth century, but its primary focus was earlier. The practically simultaneous appearance of two reprints of Manacorda's book emphasizes the revival of scholarly interest. ${ }^{7}$ Perhaps the social historians have kindled the new interest by asking such questions as: what percentage of the population attended school; and what was the relationship between school and society? Now intellectual historians, interested in the content of learning, have entered the field.

The best thing happening in the field is that historians thoroughly conversant with Renaissance intellectual currents are broadening their vision to encompass the questions raised by social historians. Anton Schindling's recent study of the Strasbourg academy shows this. Founded in 1538 and becoming a chartered university in 1621, the Strasbourg academy was a laboratory for the influences operating on Renaissance education. The city government wished to train and to keep under surveillance future leaders; nevertheless, the school became a university, a relatively autonomous corporation. It was also the setting for a curriculum struggle, between humanism and Protestant Scholasticism, between Cicero and Aristotle, to express simplistically a conflict that was far from simple. ${ }^{8}$ On a broader scale, Gerald Strauss' Luther's House of Learning assesses the attempt to produce good and learned Lutheran Christians in the sixteenth century. Based on visitation reports from many archives, analysis of humanistic pedagogical psychology, and a reading of catechetical textbooks, Strauss' study concludes that the effort totally failed. Indoctrination produced resentment and boredom rather than change. ${ }^{9}$ In France, again in the sixteenth century, George Huppert describes how civic leaders wrested control of education from the church in order to found colleges (municipal grammar schools) whose purpose was to define, to educate humanistically, and to inculcate noble values into an elite student body; in other words, they wished to produce a gentry. Structure and content reinforced each other: the schools excluded the peuple by their admission policies, and filled the heads of those admitted with Latin and Greek, further setting them apart from the population at large. ${ }^{10}$ To return to Pisa, scholars have asked similar questions about the reconstituted University of Pisa after 1543, when it was shorn of its Florentine branch. Giovanni Cascio Pratilli has studied the intervention of the Medici government into the life of the university, and Charles Schmitt, the content of studies. ${ }^{11}$

As these studies demonstrate, historians are pursuing two general themes. They are attempting to connect the academy more precisely to the social and political milieu through studying its governance and 
student constituency. And they are analyzing the curriculum. The need for the latter may seem less obvious, but its potential results are great. Grammar schools and universities institutionalized Renaissance intellectual currents, such as humanism, Aristotelianism, and Protestant theology. Even specialists in Florentine history and humanism tend to assume that humanism flowered through informal academies and other means without much contribution from the local university. Verde's study suggests that it is time to re-evaluate that assumption. In early fifteenth-century Italy, humanists normally did not hold university positions; sixteenth-century humanists, as well as philosophers, theologians, and mathematicians, frequently did.

A final manifestation of the revival of interest in Renaissance education is the appearance of an annual publication entitled History of Universities. Edited by Charles Schmitt of the Warburg Institute of the University of London, it includes studies on universities and other institutions of higher learning from the ancient world to the outbreak of World War II. The first volume (1981) focused on the sixteenth and seventeenth centuries, with articles on English and German universities (John M. Fletcher), classical instruction by French lecteurs royaux (Anthony Grafton), Salamanca (Anthony Pagden), the New Testament in Dutch universities (Henk J. De Jonge), and other studies. It also included a comprehensive and penetrating survey of recent studies on Italian universities in the Middle Ages and Renaissance by the assistant editor, Peter Denley. ${ }^{12}$ The articles and review-articles in volume I are of high quality, embodying original research in a variety of ways. The journal promises to become an excellent forum for research in the history of higher education.

The past decade has been an unusually productive one for the study of Renaissance education; the coming decade promises to be equally fruitful. ${ }^{13}$

\section{University of Toronto}

\section{Notes}

1 Gene Brucker, "Florence and its University, 1348-1434," in Action and Conviction in Early Modern Europe. Essays in Memory of E.H. Harbison, ed. Theodore K. Rabb and Jerrold E. Seigel (Princeton, N.J.: Princeton University Press, 1969), pp. 220-236.

2 See Vittorio Baldo, Alunni, maestri e scuole in Venezia alla fine del XVI secolo (Como: New Press, 1977), p. 20.

3 See two recent studies: F.L. Maschietto, Elena Lucrezia Cornaro Piscopia (1646-1684), prima donna laureata nel mondo. (Contributi alla storia dell'Università di Padova, 10.) (Padova: Antenore, 1978); and Giorgio Fedalto, "Elena Lucrezia Cornaro Piscopia (1646-1684) tra spiritualità claustrale e secolare nella Venezia del Seicento," Archivio Veneto, 5th Series, vol. 
103 (1979), 55-70. On the University of Padua in the seventeenth century, see Sandro De Bernardin, "La politica culturale della Repubblica di Venezia e l'università di Padova nel XVII secolo,"' in Studi Veneziani, 16 (1974), pp. 443-502.

4 Cronica di Giovanni Villani a miglior lezione ridotta coll' aiuto de' testi a penna. Vol. 6 (Florence: De li Magheri, 1823), Bk. XI, ch. 94 (ch. 93 in some editions), pp. 184-185.

5 Karl Julius Beloch, Bevölkerungsgeschichte Italiens. Vol. II: Die Bevölkerung des Kirchenstaates, Toscanas und der Herzogtümer am Po. Revised ed. (Berlin: Walter De Gruyter \& Co., 1965), pp. 138-39, 148.

6 Comments on Venetian education are based on my own research and on James Bruce Ross, "Venetian Schools and Teachers Fourteenth to Early Sixteenth Century: A Survey and a Study of Giovanni Battista Egnazio," Renaissance Quarterly, 39 (1976), pp. 521-566.

7 The reprints are Bologna: Arnaldo Forni Editori, 1978, in hard cover; and Florence: Casa Editrice Le lettere, 1980, with an introduction by Eugenio Garin, in soft cover.

8 Anton Schindling, Humanistiche Hochschule und freie Reichsstadt: Gymnasium und Akademie in Strassburg 1538-1621. (Veröfentlichungen des Instituts für europäische Geschichte Mainz, Abteilung Universalgeschichte, 77.) Weisbaden: Franz Steiner Verlag, 1977.

9 Gerald Strauss, Luther's House of Learning. Indoctrination of the Young in the German Reformation (Baltimore and London: The Johns Hopkins University Press, 1978).

10 George Huppert, Les Bourgeois Gentilshommes. An Essay on the Definition of Elites in Renaissance France (Chicago and London: The University of Chicago Press, 1977), ch. 7, pp. 59-83. Professor Huppert is expanding this chapter on the collèges into a monograph.

11 Giovanni Cascio Pratilli, L'Università e il Principe. Gli Studi di Siena e di Pisa tra Rinascimento e Controriforma (Florence: Leo S. Olschki Editore, 1975); and Charles B. Schmitt, "The Faculty of Arts at Pisa at the Time of Galileo," in Physis: Rivista Internazionale di Storia della Scien$z a, 14$ (1972), pp. 243-272. Both provide ample bibliographies.

12 The publisher of History of Universities is Avebury Publishing Company, Olympic House, 63 Woodside Road, Amersham, Buckinghamshire, HP6 6AA, England

13 Historians of Renaissance education will also be interested in volumes 25 and 26 of the Collected Works of Erasmus, University of Toronto Press, to be published at the end of 1982 or 1983 . The volumes include De recta pronuntiatione, De conscribendis epistolis, De civilitate, and De pueris instituendis, as well as a comprehensive summary of Erasmus' ideas on education by the general editor of the volume, J. Kelley Sowards. 